\title{
A SURVEY OF UZBEK SETTLEMENT, WITH REGARD TO SOME ECONOMIC AND SHELTER CHANGES, IN THE KHWARIZM (KHIVA) OASIS, NORTH TO THE DELTA OF THE AMU DARYA, BASED ON RUSSIAN ETHNORGRAPHIC REPPORTS
}

\author{
Harold R. BATTERSBY
}

The geographical area with which we are concerned includes the Amu Dar'ya Delta, the Kpychak, Khodzheili and Kungrad rayon (s) (district(s)) in the Kara-Kalpak Autonomous Republic, and Novyi Urgench, Gurlen, and Mangyt in the Khorezmskaya oblast' (Khwarizm province) of the Uzbek Soviet Socialist Republic. ${ }^{1}$ The Uzbek S.S.R. was established on

1 K. L. Zadykhina, "Uzbeki del'ty Amu Dar'," Trudy Khorezmskoi Archeologo-Etnograficheskoi Ekspeditsii, I, Moskva: Izd. Akad. Nauk SSR, 1952 (General ed. S. P. Tolstov, assisted by T. A. Zhdanko.), p. 319. (The principal source of material for this paper is Zadykhina's report of which there is an unpublished and unedited ms. transld. by Lawrence Krader at HRAF, New Haven.) Harold R. Battersby, The Uzbek Novel as a Source of Information Concerning Material Culture, Dissertation, Indiana University, Bloomington, 1969, p. 131. "The Khorezmian Oblast' in the southwest part of Uzbekistan, along the left bank of the lower course of the AmuDarya, is densely populated, and surrounded by vast expanses of sand. The oblast' occupies an area of 4,600 sq. kilometres, which amounts to 1.1 per cent of the total territory of Uzbekistan, while 5.5 per cent of the population of the Republic dwell here. This is one of the most densely populated oblasts of the Uzbek S.S.R., with 75 people per sq. kilometre. The Khorezmian Oblast' is a region of cotton growing and well-developed livestock raising." Zadykhina, op. cit., pp. $280,281$.

"In the pre-revolutionary period the Khorezmian Oblast' was the most backward neglected region of colonial Turkestan. The isolation of Khorezm, the absence of convenient means of communication within it, the despotic form of government, the oppressive rule of the beys and the priesthood, cruelly exploiting the workers, and the colonizing policy of the Tsarist government contributed to the preservation here of the backward feudal forms of society right up to the Great October Socialist Revolution. In comparison with other oblasts there is a large number of camels here, mostly for pack transport of goods." Ibid., p. 281. 
October 27, 1924. ${ }^{2}$

Karakalpakia is an autonomous unit incorporated within the Uzbek S.S.R. It has a population of approximately $587,000 .^{3}$ "The Khorezmskaya oblast in the southwest part of Uzbekistan, along the left bank of the lower course of the Amu Dar'ya, is densely populated, and surrounded by vast expanses of sand." Rain is rare in the region. The deeper one penetrates the desert toward Khwarizm, along the Amu Dar'ya, the blue sky brightens, and on the right stretch the sands of the Kizil Kum, yellowish-grey, and then orange, while to the left are the grey sands of the Kara Kum. Tugai, strips of low-lying greenery, trees, shrubs, and vines, like miniature jungles, give colour to the otherwise drab landscape.

We are not concerned with first settelments of man in the Neolithic Age in the oasis of Khwarizm, nor are we concerned with settlements dating from the fourth and third millenia of hunters and fishermen that have been discovered on the banks of the now dried-up River Uzboy, or that a whole system of irrigation canals existed in Khwarizm by the end of the Bronze Age. What we are concerned with are the ancestors of the Khwarizm Uzbeks, who settled in these parts, many of whom comprise the majority of the rivermen, crews of tug-boats that ply the middle reaches of the Amu Dar'ya, even in the Turkmen Soviet Socialist Republic. ${ }^{5}$

Prior to the first appearance of Uzbeks in Khwarizm in the beginning of the XVI century, the sons of the once ruler of the Golden Horde, Pulad, son of Mangu-Timur, namely Ibrahim and Arab-Shah, who were ancestors of the khans of Bukhara and Khwarizm, respectively, pitched their camps on the Yaik yaylas or Yaik heights for summer pasturage, and spent their winters in the region of the Syr Dar'ya delta. ${ }^{6}$ After Shaybani Khan, grandson, of the founder of Uzbek power, Abu'l-Khayr, conquered Transoxiana

2 Pertinent information concerning events leading to the establishment of the Uzbek S.S.R. is found in Kh. S. Sulaimanov, et al. (eds.), Istoriia Sovetskogo Gosudarstva i Prava Uzbekistana, I (1917-1924 g.g.), (Tashkent, 1960).

3 Uzbek Society for Friendship, The Uzbek Soviet Socialist Republic: 500 Facts and Figures, Tashkent, 1966, p. 6.

4 Zadykhina, op. cit., p. 280.

5 Victor Vitkovich, A Tour of Soviet Uzbekistan, Moscow, 1954, pp. 206, 207.

6 "The family tree of the Turks of the Khivan Khan Abulgazi", in translation and with an introduction by G. S. Sablukov, Comments by N. F. Katanov, Izv. Ob-va arkheologii, istorii $i$ etnografii pri Kazanskom un-te, XXI, Nos. 5-6, Kazan, 1905, p. 162. 
( ما وراء النهر mã warä' annahr "What lies beyond the river.") in 1506, ${ }^{7}$ only the sons of Yadighar Khan remained in the former domains. The Uzbek sultans, Ilbars and Bilbars, grandsons of Yadighar, their father being Baraka, migrated to Khwarizm in 1511..$^{8}$ By 1515 Ilbars had established an independent Uzbek khanate with Khiva as the capital. ${ }^{9}$

The transportation of the nomadic Uzbek was usually lightweight wickerbodied carts, drawn by oxen or horses. These carts were called arba (ara$\boldsymbol{w a}$ ), orguz-arba or chat-kokrek-arba. ${ }^{10}$ In times of emergency the Uzbeks utilized their carts as protective shelters or barricades by forming them into a circle $^{11}$ in the same manner as the early settlers of the West, in North America. The desire to reach suitable habitats motivated the migration of both the Uzbeks and the settlers of the West, but for the Uzbek, migration involved a lifetime series of movement to richer pastures. ${ }^{12}$ The majority of Uzbeks had utter contempt for a sedentary existence as a way of life, and the transposition from tents to houses leaves Uzbeks still observing die-hard traditions of nomadism. ${ }^{13}$ Whereas, and despite the old settler's adage in the West, that

7 V. V. Barthold, Four Studies on the History of Central Asia (Transld. from the Russian by V. and T. Minorsky.), I, Leiden, 1962, p. 164. Francis Henry Skrine and Edward Denison Ross, The Heart of Asia, London, 1899, p. 184. N. Elias and Edward Denison Ross, The Tarikh-iRashidi of Mirza Muhammad Haidar, London, 1895, pp. 82, 92, 180, 191, 195, 204. S. P. Tolstov, et al. (eds.), Istoriia Uzbekskoi S.S.R., I, Tashkent, 1955, pp. 405 f.

8 V. V. Bartol'd, Svedeniia ob Aralskom more $i$ nizoviakh, Amu-dari s drevneishikh vremen do XVIII v., Tashkent, 1902, pp. 75-80. Sablukov and Katanov, op. cit., pp. 172, 174-178.

9 G. Guliamov, et al. (eds.), Istoriia Uzbekskoi S.S.R., I, Tashkent, 1967, pp. 515 f. Stanley Lane-Poole, The Mohammadan Dynasties, New York, 1965, p. 278. S. P. Tolstov, Materialy Ob'edinennoi Nauchnoi Sessii, Posviashchennoi Istorii Srednei Azii i Kazakhstana v Dooktiab'skii Period, Tashkent, 1955, passim.

10 Zadykhina, op. cit., p. 344.

11 Sablukov and Katanov, op. cit., pp. 227, 297.

12 The Uzbeks had grazing lands somewhat similar to those of the North American Plains Indians including those bordering the Rocky Mountains. Incidentally, the remains of smokesignal stations are found in regions occupied by Uzbeks. S. P. Tolstov, et al., Narody Srednei Azii $i$ Kazakhstana, II, Moscow, 1963, illust. p. 399, testifies that the travois (two poles trailing from the rear of an animal to support some baggage) was not only found in the North American Plains area, for it was used in Semirech'e in 1907. Battersby, op. cit., p. 127, fn. 1. Livestock were branded. "Field Work 1946-1948", Zadykhina, op. cit., p. 344.

13 A. V. Kaulbars, "Nizovia Amu-dari, opisannye po sobstvennym", Zapiski Russkogo Geograficheskogo Obshchestva po Otdelenniu Obshchei Geografii Issledonaniiam, V 1873 g., IX, Sanktpeterburg, 1881, pp. 500, 568. O. Olufsen, The Emir of Bokhara and His Country: Journeys and Studies in Bokhara (with a Chapter on My Voyage on the Amu Darya to Khiva), London, 1911, pp. 322, 498. 
it was time to move on when smoke rose on the horizon, the majority of settlers in North America, including the cattle-and sheep-men, sought anchorage in some permanent dwelling or settlement of such dwellings--this being a result of their heritage. ${ }^{14}$

Ivanov wrote that "the first reference to a kuren 'fortified country dwelling'15 among the Uzbeks in the region of Khiva ... is found in an account concerning events of the first half of the sixteenth century," and that "the kuren was made out of $\operatorname{arba}(s)$ 'cart(s)', placed in a ring around the camp, where the agricultural population (ekinchi) kept their property and animals should they be required, while it served as a defense against enemies."

When "...the Uzbeks reached the Aral Sea,they lived in kara-uy "black tents" (yurt)," 17 and "in the territory of the Kungrad rayon they constructed a toprak ${ }^{18}$ - kala, ${ }^{19}$ erecting a rampart around it. The rampart was of beaten earth. Here the people gathered with their kara-uy(-lar). ...On the rampart they threw chengel 'prickly thorn'. The rampart was nearly five feet in height, and the several exits could be blocked with barriers and carts. ... In the winter time they gathered in the Kungrad rampart with their families." 20

14 Battersby, op. cit., p. 127.

15 qurghon قورغان "fortress, redoubt, citadel", etc., A. K. Borovkov, et al., UzbelkchaRuscha Lughat, Moskva, 1959, pp. 638, 811. Asqad Mukhtor, Opa-Singillar, Tashkent, 1958, pp. pp. 32, 33, 166. qur $\gamma$ an "fortress", Gunnar Jarring, An Eastern Turki-English Dialect Dictionary, Lund, 1964, p. 256. Tolstov, et al., op. cit., II, p. 720.

16 P. P. Ivanov, "Udelnye Zemli' Seiid-Mukhammed-khan Khivinskogo", Zapiski Instituta Vostokovedeniia Akademii Nauk S.S.R., VI, 1934, p. 34, Note 4.

17 Danilevskii (see: fn. 19) uses kara-uy also indiscriminately for "tent." "kara-uy": "kara uy (uzb. qora uy, kar. qora uy) yurta." "Glossarii", Tolstov, et al., op. cit., I, p. 712. "yourta... (nomad's tent)." Borovkov, et al., op. cit., p. 897.

18 tuproq "earth, soil, land", etc., Borovkov, et al., op. cit., p. 452. Mukhtor, op. cit., p. 166.

19 kala "strong-hold, fortress", Tolstov et al., op. cit., p. 711. G. I. Danilevskii, "Opisanie Khivinskogo Khanstva", Zapiski Russkogo Geograficheskogo Obshchestva, V, Santkpeterbug, 1851-, pp. 91-92. Elizabeth E. Bacon, in writing about the Kazaks, notes that "under the influence of settled neighbors, Kazaks began to change their way of life. Some nomads cut hay for winter fodder and built winter shelters for a portion of their animals. Some began to spend their winters in dwellings of wood, sod, or mud, depending on the house styles of their nearest neighbors, or to put up a clay wall around their encampment of yurts." Central Asians under Russian Rule: A Study in Culture Change, New York, 1966, pp. 94, 95.

20 V. Grigoriev, "Opisanie Khivinskogo Khanstva i dorogi tuda iz Saraichikovoi Kresposti”, Zapiski Russkogo Geograficheskogo Obshchestva, II, Sanktpeterburg', 1861, pp. 115-117. Zadykhina, op. cit., p. 344. Batterssby, op. cit., p. 128. 
"Anyone who wanted to live in the kala (city fortress in Kungrad rayon, built by Tore-Bii ...) built a chaten-kakyra (house made of reeds) inside it, or a tam (adobe tent) or put up a kara-uy. Whoever did not want to, lived outside the borders of the town and engaged in livestock raising, agriculture, and fishing. Often in summer they lived outside the town in a tent and in winter they went into the kala." At this time the Uzbeks did not build clay-brick houses $($ dzhai $)<$ joy $<$ uy $(-$ lar $) .{ }^{21}$

The accounts of travellers in the region between the mid-XVIII th and mid-XIX th centuries indicate a gradual development of sedentary cultural traits by the Uzbeks in these regions. Grigoriev, for example, writes that Hogg and Tomlinson, English merchants, distinguished the "Tartar-Arals" ... from the Karakalpaks, "and observed that" there were fishing boats among them." E. I. Velichko wrote, in 1803, that the nomadic "Kongrats ... are engaged in agriculture, and are equally active in fishing the Amu Dar'ya and the Aral Sea off the delta. ${ }^{22}$ They employ seines and dragnets ... made from wild hemp or that which they have grown." ${ }_{23}$

Kaulbars states that fishing "evidently occupies all the people settled on the Amu Darya Delta, consequently fish has always been an article of importance in the bazaars." This statement, of course, does not mean to imply that the Uzbeks on moving into the region immediately became fishermen. ${ }^{24}$

21 Danilevskii, op. cit., pp. 91-92. Grigoriev, op. cit., p. 117. Gregor V. Helmersen (Gel'mersen), "Khiva v nyneshnem ee sostoianii", Otechestvenny Zapiski, VIII, Moskva, 1840, p. 119.

22 Zadykhina, op. cit., pp. 319-425.

23 Danilevskii (op. cit., pp. 91-92) states: "carp and small fish are caught along the Amu Darya", and "the Arals hunt pheasants, particularly in the autumn... which they sell in the southern part of the Khanate." Helmersen noted the presence of both "hunting and farmyard dogs among the Uzbeks", op. cit., p. 199. Grigoriev, op. cit., p. 117.

24 Zadykhina, op. cit., pp. 346-347. A number of fishing techniques were learned from indigenous people, but many others were developed. Night fishing from a small boat, aided by the light of burning bundles of reeds, was successful. Kaulbars, op. cit., pp. 568-569. "kaza", made of reeds; "au, karmak, dzhilym", nets; "irgak", hooks; "narete, karse", large hoop-nets used from a "keme", boat for catching "ylak", sheatfish, were employed; and the "chachky", spear, was plunged into fish from the prow of a boat, about which a "chon", reed-chip torch, attracted fish. During the winter months fish were speared through holes in the ice. Such fish as the sheatfish, "sazan", carp; "suan", bearded fish; "chartan", pike; bekre", sturgeon; and "ak-chabak", bream were consumed fresh, being barbecued, boiled, or fried, or were preserved by smoking, salting, or drying in the wind. Zadykhina, op. cit., p. 347, and "field notes", 1948, Nos. 23, 24. S. Khodjayev, et al. (eds.), Uzbekistan na puti $k$ kommunizmu (Uzbekiston Kommunizm Yulida), Tashkent, 1964, pp. 50-51. 
Although Zadykhina quotes Matiusup Lakubov as stating: "Not only ... khans engaged in hunting but also the population, ... hunting with birds of the chase," ${ }_{25}$ I think that the momads traditionally associated fishing with humbleness, and that there is, of course, a distinction between the arranged hunts for the khans and feudal lords and the hunt of the hunter whose purpose was to supplement a meagre diet and later to balance his economy. The nomads traditionally associated hunting with noble deeds, and large-scael hunts as the sport of aristocracy. It was the lower classes that experienced the need to fish. ${ }^{26}$ Fishing does not appear to have enthused the Uzbek feudal lords. When the aristocrats were being amused by large-scale hunts, the rank and file realized they were being assembled, perhaps to be trained and disciplined for military service, or were being "kept occupied" after a campaign to maintain order. The hunt primed them for the collection of tribute or for the gaining of plunder. ${ }^{27}$

It was only with the deepest remorse that the Uzbeks began to forsake their nomadic lives for those of sedentary agriculturists. After their migration to the Lower Amu Dar'ya they found their territory to be limited and restrictive, and that the breeding of livestock was forcibly curtailed. They strived to maintain their nomadic culture traits, but were gradually being transformed into land farmers using the simplest techniques. By degrees they mastered irrigated agriculture, at first employing primitive water raising devices (serppe-chigir), but gradually becoming more sophisticated in their new vocations, developed larger reservoirs, better canals, and generally more efficient means to supply water to their crops.28

25 Zadykhina, op. cit., p. 347; "field notes", 1948, No. 28.

26 Fish or other water game does not have to be slaughtered. They can be eaten whether caught by a Magian, Jew or Christian, or even if they are washed ashore, providing they do not have a bad odor. ... al-Ṣaḥih al-Buḳhārī by al-Ḥāfiz Abū 'Abd-Allāh Muḥammad ibn Ismā'il al-Buḳhāri, 5: 96; 72: 11. Les traditions islamiques trad. de l'arabe, by 0 . Houdas and W. Marçais, Paris, 1903-1914.

27 Kaulbars, op. cit., pp. 574-575. Zadykhina, op. cit., p. 347; "field notes", 1948, Nos. $23,28$.

28 Ibid., pp. 347-349. M. N. Ermolaev, Propusk vod R. Amu-Dar'i v Mervskii $i$ Tedzhenskii Oazisy s Tsel'iu Orosheniia 516,000 Desiatin Zemli v Vostochoi Chasti Zakaspiiskoi Oblasti, (90) Sanktpeterburg', 19è8, pp. 1-26. V. V. Rusinov, Vodozemel'nye Otnosheniia i Obshchina u Turkmen; Doklad, Chitannyi v Zasediiakh T.S.-E.O., 2-GO I 9-GO Iiuna 1918g., Tashkent, 1918, pp. 1-55. Kh. Inoyatov, Central Asia and Kazakhstan Before and After the October Revolution, Moscow, 1966, pp. 14f. 
With the passage of time the proud nomadic Uzbek became partially adjusted to sedentary "Sart culture." ${ }_{29}$ It was the Sarts, whom the Uzbeks had once considered "sissies and effeminate", ${ }^{30}$ that taught the latter irrigation, agricultural cultivation, and dwelling construction techniques that they had practiced for a very long time. ${ }^{31}$ Between 1925-1928 land and water reforms were supported by the Communist Party, and while beylandlord land titles were abolished, the land thus previously held was given over to peasants $^{32}$ or kolkhoz(es) (collective farm(s)). ${ }^{33}$ By 1948 mechanization of the kolkhozes was accomplished, but the peasants continued to use the kunde-, omach-, and sokha-ploughs, and the mala-levelers, and other such primitive tools, to cultivate their personal land, as in previous years. ${ }^{34}$ Since the Communist take-over, energy has been expended in draining swamps and in repairing old and building new irrigation systems. Horticulture and tree planting have been encouraged. Fruit trees and others of economic importance, such as the poplar

29 The Sarts were not an ethnic group, but settled groups of Turks, Tajiks, etc., ${ }^{*}$ and it was not until later that the term Sart was used to distinguish Turkic-speaking oases dwellers from the Tajik-speaking town dwellers. The Soviets fropped the term Sart after the 1917 Revolutio, and splint the "Sart population" on the basis of linguistic criteria. Thus, they classified SartUzbeks as Uzbeks, and Sart-Tajiks as Tajiks.**

* Eugene Schuyler, Turkistan (edited with an introduction by Geoffrey Wheeler; abridged by K. E. West), London, 1966, p. 51. Waldemar Jochelson, eoples of Asiatic Russia, New York: The American Museum of Natural History, 1928, p. 169.

** Lawrence Krader, Peoples of Central Asia, Bloomington-The Hague, 1962, p. 69. Harold R. Battersby, "The Central Asin Terms Uzbek, Sārt, and Tājik", Communication 89, presented at the One Hundred and Eightieth Meeting of the American Oriental Society at Baltimore, April 15, 1970, pp. 2, 3, 4.

30 Schuyler, op. cit., p. 51 .

31 Zadykhina, op. cit., p. 348. The Uzbek novel, Opa-Singillar (Ikkinchi Nashri), by Asqad Mukhtor, Toshkent, 1958, has references to Ergash, an Uzbek, who, in 1921, apprenticed himself to Tajik masterbuilders in a qishloq (kishlak) "village", pp. 11, 157. He later became chief of a a mill building project. Ibid., p. 245. Harold R. Battersby, The Uzbek Novel as a Source of)Information Concerning Material Culture, p. 36, fns. 2, 3; p. 37, fn. 2. Tolstov, et al., pp. 429f.

32 "Since the clan and tribal system was firmly rooted in Khoresm, the local Soviets in the Turkmen areas were not created on territorial basis as was the case elsewhere, but on a clan basis (clan Soviets). The land formerly owned by the Khiva Khan was distributed among the village poor." A. Roslyakov and Sh. Tashliev, How Socialism Came to Central Asia, Moscow, c. 1970 , p. 56.

33 Kolkhozes were organized between 1926-1927. Consult the index of: Sh. B. Batyrov, et al. (eds.), Pobeda Sovetskoi Vlasti v Srednei Azii $i$ Kazakstane, Tashkent, 1967, and the map on p. 352 for advancement of Soviet power in the Khwarizm Oasis.

34 Zadykhina, op. cit., p. 351. U.S.S.R. Uzbekistan: Uzbek Soviet Socialist Republic, Novosti Press Agency Publishing House, n. p., n. d., pp. 32 f. 
and mulberry, the latter for sericulture, have been planted. At the Lenin Kolkhoz in the Kungrad rayon, the main activity is livestock raising. This has been supported by increases in fodder production, which in turn encouraged the establishment of a beekeeping brigade. Cotton has become the principal crop, but wheat, millet, sorghum, rice, barley; legumes, mung beans; alfalfa, clover; and some tobacco are grown. Slowly, vegetable raising increased. Onions, carrots, peppers, muskmelons, watermelons, and pumpkins were grown in earlier times, but cucumbers, beetroots, potatoes, cabbage, and tomatoes were first cultivated in gardens of kolkhozes in 1931. ${ }^{35}$ Ornamental flower gardens, often with shrubs, have become increasingly popular. ${ }^{36}$

It was in the 1840's that Gladyshev wrote: "Those Aral people live near the Aral Sea, near the Ulu Darya (Ulu river) and along both sides, starting from the very large mouth and going upward. On the right bank they live as far as the Kula-Bii river, and on the left bank as far as the Bish-Tyube mountains... while others nomadize with tents in numbers of hundred and up to five hundred." At that time, according to him, the southern or Khivan Uzbeks had houses made of clay, but along with them "many also kept tents."

Muraviev noted in the XIX th century that "...their dwellings are the simplest and poorest. The majority of the people nomadize the entire year in felt tents. Even rich people with houses live in these tents from being accustomed to nomadic life. Their buildings do not have a view of the outside and are constructed of clay." ${ }^{38}$

35 Dzhapak Abraimov, lived with relatives in the Tashauz rayon (district) between 1921 and 1924. They grew vegetables that had previously been unknown to him; he collected seeds and studied gardening, and later instrueted at kolkhozes and agricultural institutions. He remembers his bringing seeds into the Lenin Kolkhoz region. "At first Abraimov grew them alone in his own personal sector, since the people were mistrustful of him when they saw these vegetables at his house which they did not know. Later, however, a number began to take seeds from him. They asked his advice on when and how to sow them in the land they were permitted to cultivate, and eventually his neighbours and the region became accustomed to vegetable growing." Zadykhina, op. cit., pp. 349-353, and "field notes" 1948, No. 114. Karim Mahkmudov, Uzbek Taomlari (Ikkinchi Nashri), Tashkent, 1963, passim. Khodjayev, et al. (eds.), op. cit., passim.

36 Ibid., passim. Mukhtor, op. cit., pp. 339, 387, 393, 398.

37 Gladyshev and Muravin, Poezdka iz Orska $v$ Khivu i obratno, sovershennaia $v$ 1740-1741 gg., Sanktpeterburg' (Iz. V. Khanykov), 1851, pp. 20, 72-74.

38 M. N. Muraviev, Puteshestvie v Turkmeniiu $i$ Khivu v 1819-1820 gg., II, Moskva, p. 129. 
Helmersen said in 1826 that "the Uzbeks of the Kungrad region nomadize from place to place, and have no permanent dwellings, but the Uzbeks of the southern regions of the Khanate live in houses, and in summer in tents in fields. ... In Khiva, in the Tash-Khauli, the palace of the khans of the Uzbek Kungrad dynasty, built in the first half of the nineteenth century, there are preserved round platforms for tents, with brick foundations. ${ }^{39}$ According to the descriptions of travellers of the nineteenth century, the first khans not only arranged receptions in tents, but also used them themselves as their customary dwellings." 40

Delta Uzbeks in the XVIII th and first half of the XIX th centuries were semi-nomadic, being restricted in movement by their agricultural and fishing occupations. The Uzbeks to the south were already much more settled, but found it difficult to forsake the kara-uy "tents", and pitched them in their courtyards (howli (Khauli), joy), field and orchards.41

In 1873 Kaulbars noted that "the Aral Uzbeks possess permanent sectors of land, surround them with fences, and have allowed dense orchards to grow up in them. In general, they have adopted a completely sedentary form of life, and the only sign of their former nomadic life, is the fact that they still live primarily in felt tents, put up in the middle of courtyards, which are built up with the solid mud huts." ${ }_{42}$

Zadykhina says "the tent was almost lost in the south of the Khorezmian oasis, with the adobe house and courtyard replacing all that went before. ... Fifteen years ago all had tents, pitching them in summer in front of the house, and in the aywan ${ }^{43}$ in winter. A man who did not have a tent made himself a mud hut (tule). The tents of the poor were bad and old, and those of the

39 Enri Moser, D Traverse l'Asie Centrale la Steppe Kirghize, le Turkestan Russe, Bukhara, Khiva, le Pays des Turcomans et la Perse: Impressions de Voyage, Paris, 1885, illust. "Palais du Khan de Khiva", p. 253. Note round platforms, one of which is occupied by a tent. Observe their height, as measured by the man sitting on the edge of the one in the foreground. His leg, knee to thigh, is level. Zadykhina, op. cit., fig. 4, pp 352-353

40 Helmersen, op. cit., pp. 101, 1 è2.

41 Danilevski, op. cit., p. 92. Zadykhina, op. cit., p. 354.

42 Kaulbars, op. cit., pp. 500, 568. Tolstov, et al. (eds.), op. cit., I, pp. 466-49è; II, pp. 73-77. U.S.S.R. Turkmenia: The Turkmen Soviet Socialist Republic, Novosti Press Agency Publishing House, n. p., n. d., p. 13.

43 aywon "verandah, open gallery, portico", Borovkov, op. cit., p. 26. 
rich were beautiful and large $($ otau $) \ldots{ }^{44}$

The Uzbek tent reveals characteristics of the transformation of it into a more or less sedentary dwelling. It is three times heavier than a Kazak or Karakalpak tent for reasons of its structural characteristics. Undoubtedly, the Kazaks and Karakalpaks were forced to continue to make light tents for convenience in moving more frequently and for greater distances. ${ }^{45}$

The main parts of the tent are the kerege "the wattle sides," the $u k$ "wooden poles forming the cupola of the tent" and having a convex form, and the changrak "a wooden hoop" in which the $u k$ are inserted. The Uzbek and Karakalpak tents have more height than the Kazak tent, and while the former are cone -shaped, the latter are squatter and more spherical. The sturdy wooden framework of the Uzbek tent is left unpainted, but the Kazaks and Karakalpaks colour theirs red. The Uzbek kerege sticks are rounder and thicker, and more closely set than those in Kazak and Karakalpak wattle sides, making the kerege-kŭz "wattle eye" or "interstice" smaller, and therefore indicative of a greater weight. Wooden parts are still prepared by the uychi, a mastercraftsman in tent-frame-making. ${ }^{46}$ Pieces of felt and chiy mats are used in houses today as they were in tents. ${ }^{47}$

44 Zadykhina, op. cit., pp. 434, 352, 353, 354, 355. Bacon, who resided in the Soviet Union during the academic year 1933-34, writes: "The people of Central Asia have shown a strong tendency to cling to their traditional occupations. Pastoral nomadism has survived vicissitudes that seemed certain to extinguish it, and as of 1965 , it flourished with the blessing of the Soviet government.* A larger proportion of the pastoral population than formerly is sedentary, engaging in some dry farming and dairying as well as the breeding of horses, sheep, and camels, and alternating between permanent dwellings in winter and yurts in summer, but traditional pattern itself is as old as the history of Central Asia." op. cit., p. 202.

* An interesting photograph appears on page 6 , in the socialistic monthly, Northern Neighbors, No. 119, April, 1967 (Gravenhurst, Canada). It shows “ancient skin 'yurtas' being replaced by nylons!" in Tajikistan; i. e., the outer skin covering is replaced by nylon.

45 Battersby, op. cit., p. 132. Zadykhina states: "Field observations made from 19461948 make it possible to establish a concept of the evolution of the dwelling of the Uzbeks from the nomadic to the sedentary type." op. cit., p. 355 .

46 Ibid., pp. 355, 356, 357, 358; but see Tolstov, et al., op. cit., illustrs. pp. 223, 287, 469, 470, 475, 515. "Charpente de la yourte", Moser, op. cit., illust. p. 50. Battersby, op. cit., pp. 132133.

47 namat "thick felt", used on floors, at doors and windows. Borovkov, op. cit., p. 280. kigiz, ibid., p. 212. Mukhtor, op. cit., pp. 1è8, 367, 4è9, 416. Traditional methods of felt-making appear to differ very slightly among Turkic people. My observations in Turkey suggest the "Mervi women making felt", illust. on p. 84, Woolrych Perowne, treat the raw material to similar processes as do Anatolian manufacturers. J. T. Woolrych Perowne, Russian Hosts and Eng- 
Gradually, "two (predominant) types of adobe houses and courtyards" were made, of which the first "the khauli $^{48}$ which was roomier was considered "Sart'." The second, "the $d z h a i^{49}$ was considered Uzbek. It differs from the khauli in that it has smaller dimensions and fewer rooms inside." 50

Today, many kinds of sedentary dwellings are erected in the Khwarizm Oasis, a region that has not lacked architectural finesse. The most commonly employed word for an erected shelter is $u y$ "house, dwelling, apartment, living quarters, tent," ${ }^{51}$ etc. This is a vague term. Chorbogh is often used for the "villa"-type of "country house." ${ }^{2}$ Kulba refers to a "hovel, hut, shanty, chack", 53 etc., and barak to "barrack" -type dwellings. ${ }^{54}$

Whatever the dwelling, for a time, grass was still hung near the entrance to ward off the evil eye; and when there was no tent, the aywon "verandah" was the summer quarters. Thus, the qish turarjoy or qish uy "winter apartment / quarters" was usually occupied from the middle of November or December until March or April, depending on weather conditions. During March or April the household moved out into the aywon. In some regions there were inner courtyard verandahs that were used in the spring by the women. These were called qafes aywon(-lar) "cage verandah(s)", significant of seclusion, and divorced of conceptions of nomadic freedom. Any verandah situated in view view of public eyes and used by women had some sort of screen, usually a dense lattice of reeds or small faggots put up in front of it, that the women could look out without being seen. ${ }^{55}$ When summer began, the household moved into the ters aywon "opposite verandah", 56 taking advantage of the

lish Guests in Central Asia, London, 1898. Chiy "a grass or reed" (Arundilla nepanlensis), "used for making baskets and mats", Borovkov, op. cit., p. 520. chiy bûyra "chiy-/grass mat" used as a sunshade on a verandah", Mukhtor, op. cit, pp. 113, 114, 395. "Dense lattices of reeds or small faggots are put up in front of verandahs used by women so that they may look out without being seen themselves." Olufsen, op. cit., p. 312. Battersby, op. cit., p. 133 and fn. 2.

48 howli "court, yard, courtyard"; howli joy "farmstead, countryseat, country estate", Borovkov, op. cit. ,pp. 659-660.

49 joy "place", uy-joy, howli-joy "house, farmstead," etc. Ibid., p. 157.

50 Zadykhina, op .cit., p. 355.

51 Borovkov, op. cit., p. 473.

52 Ibid., p. 527. Mukhtor, op. cit., p. 6.

53 Borovkov, op. cit., p. 222.

54 Ibid., p. 54.

55 See fn. 47 above.

56 This "is always built on the north side to take advantage of protection during the heat of the day. ..." Zadykhina, op. cit., pp. 362, 363 . 
maximum amount of shade and coolness. About the middle of September a transfer was made again to the verandah (south side), and then in November or December to winter quarters. Much of the year then, under these conditions, was spent outside the rooms of the adobe houses. ${ }^{57}$ The town houses with small courtyards were ideally planned to have summer rooms facing north, and winter rooms facing south. ${ }^{58}$ In winter, depending on location, the flat roof is often used by women to imbibe the midday sun, and in summer, on occasion, entire families may sleep there at night. ${ }^{59}$

Types and sizes of houses and courtyards depended much upon the income and class of the occupants. The beys owned large estates, while the poor and class of the occupants. The beys owned large estates, while the poor had to seek whatever shelter they could afford. The loy kulba/tule, tule-joy "mud hut" was the first type of permanent dwelling the Uzbeks learned to build. It is still built, more as a temporary shelter, and is a heated winter dwelling. It is semi-underground, that is the floor level is below that of the ground. The inclined oghiz "entrance" is frequently closed by a piece of thick felt or a plain wooden door. The walls above ground level are adobe and the roof is supported by a central longitudinal beam, on which traverse beams are set. These are liberally covered with branches, grass, reeds, straw, or any other such binding material available, then topped by soil. Wall columns (deworustunlar/bakanlar) support the main roof-timbers. The roof has two inclines. A stove partitions the interior into two unequal parts. The household equipment is stored in the smaller, front part, and the larger, back part is occupied by the household. Lighting is accomplished by leaving openings in the roof or below the roof in theside walls. Ablutions are performed over a pit with spaced boards, near the entrance. ${ }^{60}$

The kakra dwelling is the second simple shelter. It may be either square or rectangular in shape. It has a skeletal structure of posts and beams that is usually filled in with reeds covered with mud mixed with chopped straw. The

57 Ibid., pp. $359,360$.

58 Arthur Sprague says: "In Khiva, the axes of the âywans were always strictly oriented north and south, the windows to the north being the main ones of the summer rooms and the winter quarters facing the south. The âywan is actually an outdoor living room, and the scarce wood was used in its construction", "Modernizing Architecture, Art, and Town Plans", Central Asia: A Centruty of Russian Rule (ed. Edward Allworth), New York and London, 1967, p. 497. 59 Battersby, op. cit., pp. 134-135.

60 Ibid., p. 136. Zadykhina, op. cit., pp. 361-362. The loy kulba/tule-type of shelter is found in Europe, e. g., Greece, and through Asia into China. 
roof is flat and laid on poles that are covered with reeds or branches, and topped with packed earth. Usually there is no chimildiq pesh "stove," but in the wall adjacent to the entrance a tandir-üchoq "oven" for cooking flat-cakes (bread) is built. An opening over the door permits the escape of smoke and in the south wall there is a frameless window to provide light. The door is wooden, and may have two folds. Sometimes thick felt is used in place of a wooden door. On the north side a canopied area may be built to form an aywon, and here occupants usually spend the summer months. ${ }^{62}$

Undoubtedly, the joy or $u y$-joy is the most wide-spread type of dwelling. It is a rectangular structure, having two inhabited rooms with a yülak or dahliz "corridor" ${ }^{33}$ between them. The yard entrance gate or door usually faces south. Often one side of the corridor is utilized for a sigir-khona or oghil (khona), "cow" or "cattleshed"4". The almost square joy with mol-qora $<$ (molqüra $)^{65}$ "livestock, cattle, enclosure" or quarters attached, has walls of brushwood covered with clay. Where clay is plentiful the majority of the walls are built-up of solid mud blocks, and pellets, or sun-dried bricks. ${ }^{66}$ The entrance to the building is on the northern side, and here an open aywon or ters-aywon is built. To the side of this stands the tandir-üchoq. Even today many households erect a tent on the ters-ayßon. A stove partitions the living quarters into unequal parts, one to live in and the other for work. ${ }^{67}$

The hoßli-joy is "a house with grounds and outbuildings" house or seat, farmstead, or type of estate that usually belonged to beys. More wood, stone, and perhaps even kiln-fired bricks were used in the construction, although most frequently, the rich and poor alike, built principally of

61 See fn. 78 below.

62 Battersby, op, cit., pp. 136-137. Zadykhina, op. cit., p. 362.

63 yulak "corridor, passage", etc.; dahliz" "passage, entrance (hall), ante-room", etc., Borovkov, op. cit., pp. 194 and 123 respectively.

* Spelt "daliz" by Zadykhina, op. cit., p. 362.

64 molkhona "cattle-shed, cow-house, (sheep-cattle)", Borovkov, op. cit., p. 266; sigirkhona "cowshed", p. 365; oghilkona < oghil "cowhouse, sheepcote", etc., p. 314.

65 molqûra "fold, enclosure for livestock", ibid., p. 266.

66 khom ghisht "unbaked brick", guyala deworlar "clay (pellet) walls", Mukhtor, op. cit., pp. 6, 218, 277, 462, 478. Battersby, op. cit., p. 138, fn. 2. For Uzbek and Tajik wall-building techniques see Tolstov, et al., I, p. 589; II, pp. 63 . Since the Revolution the use of baked bricks has been considerably increased.

67 Zadykhina, op. cit., pp. 362-363.

68 Borovkov, op. cit., p. 659 . "hojli $\simeq$ hojle $\simeq$ hojla A. P. حوبيلى courtyard, yard, house, palace; jer h. farm”, Jarring, op. cit., p. 122. 
loy or pakhsa "clay, mud." Actually, the howli-joy-type of dwelling frequently looks like a small fortress, being rectangular and having blank walls about three metres high, and one darwoza "gate" on the southside. This gate invariably has two wings, and perhaps a wicket gate in one of them or to one side of it. ${ }^{69}$ The living quarters are situated to the left and right of the gate. Two rooms (or more) are on the left side. They are usually about the same size, and in front of them an open aywon is built. This is always built on the north side to secure maximum shade and protection from the heat. Within the ters-aywon an $u y$-joy, "place for a tent", used to be made with the entrance facing south. The ichkari "women's apartment" 10 was customarily cut off from the mehmonkhona "guest-room". The mehmonkhona was reserved primarily for males, and served the purpose of the Turkish selamlik.

The mehmonkhona was adjoined to the aywon, and beyond was the pichan bosiladigan bolokhona or tupan-khona "hay-loft". The Uzbeks' love of water frequently induced him to have a howuz "pool" shaded by a tree in his courtyard. Favourite trees for this purpose are the chinor "plane tree", the qaraghoch "elm", and the iwa "willow" ", The howuz served the practical purpose of a reservoir. ${ }^{72}$ To the right of the gate smaller apartments were built with a yülak "corridor" and a living-room. In front was another open aywon on which there used to be a place for a qora-uy "tent" at the far end of the howli "yard" was the closed quarters for the livestock, which had a large entrance gate directly in line with the outer gate. A wide yülak or dalon"4 "passage" or "corridor" lead from the outer gate to that of

69 Olufsen noted (op. cit., p. 305) that "only low, narrow doors lead into houses ... and if the house belongs to the well-to-do man, the two-leaved gate is well barred." Most of the dwellings had small courtyards, in consequence of which, occupants owning carts had to leave them outside their yard walls. Battersby, op. cit., p. 140, fn. 4.

70 The ichkari howli, "inner courtyard", was reached, usually, by passing along a passage, or even through a door or gate, from the tashqari howli, "outer yard", which was used more publicly. Ibid., p. 139, fn. 2.

71 Ibid., fn. 4.

72 There is also the term anhor ombor "canal reservoir." anhor is derived from the Arabic plural from i انهار from the singular "a stream of runnign water, a river, a brook", Borovkov, op. cit., p. 36; Sir James W'. Redhouse, A Turkish and English Lexicon, Constantinople (Istanbul), 1921, p. 2114; Arabic "نز "to dig (a channel) for a river", J. G. Hava, Arabic-English Dictionary, Beirut, 1951, p. 803. Battersby, op. cit., p. 139, fn. 5.

73 See fn. 19 herein.

74 Borovkov, op. cit., p. 194; dalon $\simeq$ dolon, ibid., pp. 118, 131. 
the sigir-khona or oghil (-khona) "cowshed" 7 allowing the passage of arbalar $<$ arawalar "two-wheeled carts."

Consciously and subconsciously the sedentary Uzbek seems to be drawn, as though by a magnet, toward past nomadic non-material and material culture traits. The pitching of tents on special platforms or on the ground, the mowing from winter to summer living quarters, and the sojourns at yaylas, are part and parcel of the Uzbek's heritage. Further evidence of conservatism can be seen in the division of sedentary dwellings "in the manner of the tent. Here, as in the tent, they differentiate the honoured place (tor-bet), the work side (kazan-bet), the passageway (aden), etc. The central beam of the ceiling is supported by posts called bakan. The smoke aperture is called tongliuk, ${ }^{77}$ as in the tent. When, in some houses, there is the kind of oven which divides the living quarters into two parts, it is called chemyldyk-pesh,,$^{78} \mathrm{i}$. e., they give it the term which usually means the curtain in the tent." ${ }_{9}$

The living quarters, even during the first half of the nineteen hundreds, were very seldom furnished with stoves, and, just as for the tent, a hole in the roof or wall permitted light to infiltrate through smoke leaving it from the hearth. Modern and also prestige features are many and varied. They include: window apertures, at first unframed but later both framed and glazed; tables, chairs, paint, white-wash, buffets, bookcases, and more lately, corrugated iron roofs, foundations, better toilet and ablution facilities. The gungra-pesh "round iron stove" was given that name because of their resemblance in shape to the "halfcolumns of the Khivan howli." The packed dirt floors are, for the most part, now replaced by kiln-baked brick or wooden coverings. Many dwelling compounds now include towuk-katak(-lar) "chicken housss(s)" or "co-

75 Skrine and Ross, op. cit., illust. pp. 212-213.

76 Zadykhina, op. cit., pp. 362-363. Most of the poorer people had dwellings with yards, but their carts had to be left outside their coyrtyard walls. Olufsen noted (op. cit., p. 305) that: "Only low, narrow doors lead into houses ... and if the house belongs to the well-to-do man, the two-leaved gate is well barred." V. P. Semenov-Tian-Sanskii (ed.), Rossiia. Polnoe Geograficheskoe Opisanie Nashego Otechestva, XIX, Turkestanskii Krai, Santkpeterburg, 1913, pp. 224f. Battersby, op. cit., pp. 138, 139, 14è and fns. 3, 4, 5 .

77 tanglik, Borovkov, op. cit., p. 404.

78 “chimilik (tadj. chimiliq) 'nuptial curtain', Tolstov, et al., op. cit., I, p. 723. chimi/diq see gŭshanga "curtain, (bed-) curtain", Borovkov, op .cit., pp. 521, 116. pesh < Russ. pech' "stove, oven", A. I. Smirnitsky, Russian-English Dictionary, Moscow, 1959, p. 523.

79 Zadykhina, op. cit., p. 368. 
up(s)", and it-katak(-lar) "dog kennel(s) $)^{\mathrm{s} 0 "}$.

Constant and rapid changes are taking place in all realms of the nonmaterial and material culture of Uzbeks in the Khwarizm Oasis, north to the Delta of the Amu Dar'ya. Each change is giving rise to a more complex sedentary way of life that more greatly restricts their nomadic heritage.

80 Borovkov, op. cit., pp. 184-185, 204, 439. Zadykhina, op. cit., pp. 365-370. 